\title{
O CÓDIGO DE PROCESSO CIVIL DE 2015 E A TEORIA DA AÇÃo COMUNICATIVA DE JURGEN HABERMAS
}

\section{Luiz Fernando Bellinetti1* Ricardo Benvenhu2**}

\begin{abstract}
Resumo
O presente trabalho teve por objetivo analisar o fenômeno da constitucionalização do processo a partir da vigência do Código de Processo Civil de 2015, mais adequado aos ideais de justiça, efetividade e pacificação social. Os institutos idealizados no diploma processual representam a concretização dos direitos fundamentais tutelados pelo Estado Democrático de Direito. Pretende-se estabelecer um paralelo entre a ideologia adotada pelo CPC e a teoria da ação comunicativa, criada por Jürgen Habermas, que semelhante aos propósitos de colaboração e participação democrática, utiliza a linguagem para alcançar o consenso. Adotou-se o método dedutivo com base em pesquisa de legislação e doutrina.
\end{abstract}

Palavras-chave: Código de Processo Civil de 2015. Teoria da Ação Comunicativa. Jurgen Habermas.

\section{CODE OF CIVIL PROCEDURE AND THE THEORY OF COMMUNICATIVE ACTION JURGEN HABERMAS}

\begin{abstract}
This work analyses the constitutionalization of the judicial process since the Brazilian Civil Procedure Code 2015 (Brazilian CPC) which elevates the ideal of justice, effectiveness and social pacification as fundamental rights protected by the Democratic State of Law. This work also aims to stablish a conection between the concepts adopted by the Brazilian CPC and the Communication Action by Jürgen Habermas, which also uses language to achieve the consensus such as colaboration purposes and democratic participation do. The legislation and doctrine research were based on the the deductive method.
\end{abstract}

Keywords: Brazilian Civil Procedure Code 2015. Communicative Action Theory. Jurgen Habermas

\section{INTRODUÇÃO}

1 Mestre em Direito pela UEL e Doutor em Direito pela PUC-SP. Procurador de Justiça Aposentado. Advogado. Professor dos Cursos de graduação e pós-graduação em Direito da UEL. E-mail: luizbel@uol.com.br; endereço: Departamento de Direito Privado/CESA/UEL. Rodovia Celso Garcia Cid, PR-445, Km 380 - Campus Universitário, Londrina - PR, 86057-970.

2 Especialista pela Fundação Escola do Ministério Público do Estado do Paraná. Mestrando em Direito Negocial pela Universidade Estadual de Londrina. Promotor de Justiça do Estado do Paraná, lotado na Promotoria de Proteção ao Patrimônio Público da Comarca de Londrina. E-mail: rbenvenhu@ yahoo.com.br; endereço postal: Rua Capitão Pedro Rufino, nº 605, CEP 86.015-700, Londrina/PR. 
Compreender o fenômeno da evolução humana, caracterizado por inúmeros fatores de ordem econômica, política e social, demanda uma análise conglobada com o sistema jurídico nacional, cuja função precípua seria resguardar os direitos violados.

Observou-se, na contramão do dinamismo social, que os instrumentos gizados pelo Código de Processo Civil de 1973 não abarcavam às situações jurídicas conflituosas surgidas no final do século passado, ao menos sob a perspectiva adotada pela Constituição Federal de 1988.

Exigiu-se a concretização jurídica dos vetores constitucionais destinados a garantir o acesso à justiça que seja célere e eficaz. Essa nova ordem, inclusive, motivou diversos movimentos de reforma do Código de Processo Civil de 1973, cujos instrumentos irradiavam exagerados tecnicismos aniquiladores dos ditames enraizados na magna carta. Nesse viés, a Constituição Federal impulsionou as principais alterações processuais, com a finalidade de, a um só tempo, tutelar os direitos fundamentais e às liberdades.

Essas reformas, embora necessárias e positivas, não atingiram os escopos idealizados pela Constituição Federal, especialmente quanto ao compromisso assumido pelo Estado em promover uma tutela efetivamente justa e democrática. Nessa ordem, fez-se imprescindível o progresso e atualização das normas processuais que se compatibilizassem com a pretensão jurisdicional almejada.

E, exatamente para contemplar os anseios da sociedade contemporânea, no sentido de conferir verdadeira sintonia entre o processo civil e a Constituição Federal, edita-se o Código de Processo Civil de 2015, cujo objetivo primordial foi consagrar o fenômeno da constitucionalização do processo, mediante a observância obrigatória dos princípios e valores materializados na magna carta.

Nesse contexto, inova-se o sistema processual, que passa a ser aplicado a partir da perspectiva democrática. Não se envidou esforços para disciplinar, no âmbito processual, o discurso aberto, colaborativo e democrático, fundado na participação das partes, que juntas pretendem construir uma tutela justa, tempestiva e adequada, mediante o respeito ao devido processo legal constitucional.

Por sua vez, o filósofo Jurgen Habermas, por intermédio da teoria da ação comunicativa, defende o estabelecimento de condições de entendimento entre os sujeitos, que devem abandonar o egocentrismo e se submeterem aos critérios públicos de racionalidade. Replicando os ensinamentos habermasiano para o âmbito processual, vislumbra-se que a força 
cogente do direito decorre, em essência, de um procedimento racional-discursivo em que se garanta aos participantes em grau de igualdade, por meio da argumentação, a possibilidade de influir no resultado final.

A partir de tal perspectiva, o presente trabalho se propõe a analisar, por meio do método dedutivo, com base em pesquisa de legislação, doutrina e jurisprudência, o estudo da relação entre os vetores idealizados no Código de Processo Civil de 2015, notadamente a dialeticidade, cooperação e colaboração democrática, com o discurso de Habermas, fundado na teoria da ação comunicativa.

\section{O CÓDIGO DE PROCESSO CIVIL DE 2015}

O Código de Processo Civil de 1973 previa mecanismos absolutamente incapazes de abranger a complexidade das relações jurídicas do cotidiano. Seus institutos, porque desconectados com os valores gizados na Constituição Federal, não se destinavam a tutelar o direito material. Tanto que o diploma passou, ao longo dos anos, por diversas reformas que almejaram empregar efetividade no sistema processual.

Observa-se, nessa linha, que as regras processuais do revogado Código, promulgado ainda durante o regime militar, foram idealizadas sob a ótica social da época, cujos instrumentos refletiam a cultura da litigiosidade.

É de se ressaltar que o modo litigioso de analisar o sistema processual não se restringiu ao legislador. Os acadêmicos e os profissionais do Direito, por muitos anos, defendiam que a solução do embate processual entre as partes somente poderia advir do Estado, em razão do monopólio jurisdicional. Por décadas, inexistia a adoção de técnicas alternativas de pacificação social, o que ocasionou, sem sombra de dúvidas, um verdadeiro colapso no sistema judicial brasileiro, que não está preparado para dar vazão a infinidade de processos. Pode-se falar, inclusive, em crise da justiça, efetivamente à beira do colapso ${ }^{3}$.

No mais das vezes, às diretrizes do Código de Processo Civil de 1973 acabavam por procrastinar a solução da lide, com burocracias e recursos desnecessários, o que certamente causava entrave processual e morosidade do sistema.

3 Existiam 114 milhões de processos judiciais em trâmite no Brasil no ano de 2020. "https://espacovital.jusbrasil.com.br/noticias/150699708/previsoes-sombrias-114-milhoes-de-processos-na-justicabrasileira-em-2020" 
Nesse sentido já relatava Mauro Cappelletti (2002, p. 35):

\begin{abstract}
"O CPC brasileiro, porém, ao longo de sua vigência, a despeito de ser um monumento jurídico-científico, tem revelado descompasso com sua finalidade primeira, que é a instrumentalização da obtenção do direito material. Não tem sido raro falar em crise do processo civil ou crise do judiciário. A busca por aperfeiçoamentos tem gerado a edição de muitas leis federais com o objetivo de modificar o CPC, o que, se por um lado é positivo em razão da evolução do sistema, de outro é extremamente pernicioso, devido à quebra da 'sistematicidade' que justifica a existência de um Código."
\end{abstract}

Não se desconhece, a toda evidência, que as normas previstas no Código de Processo Civil de 1973 ressaltavam o poder geral estatal absolutamente impositivo e superior à vontade das partes, sendo inconcebível, à época, qualquer solução negocial que incidisse sobre as regras procedimentais. O processo, por vezes, não atendia a sua finalidade em virtude do regramento processual engessado.

Assim é que existia assimetria na condução processual, com o magistrado ocupando posição de ascendência às partes e pautado pela aplicação sistêmica da legislação. Nas palavras de Giuseppe Chiovenda (2010, p. 35), a jurisdição “consiste na substituição definitiva e obrigatória da atividade intelectual não só das partes, mas de todos os cidadãos, pela atividade intelectual do juiz, ao afirmar existente ou não existente uma vontade concreta da lei em relação às partes."

É fato, portanto, que o revogado Código de Processo Civil empregava o formalismo excessivo em detrimento dos sujeitos da relação processual, inexistindo margem de flexibilização procedimental, a despeito das constantes modificações das relações sociais. E as consequências advindas deste sistema são nefastas, sob a perspectiva constitucional.

Sobre o tema, relevante citar a lição de Carlos Alberto Álvaro de Oliveira (2009, p. 47):

\footnotetext{
"Impõe-se afastar o formalismo oco e vazio, incapaz de servir às finalidades essenciais do processo - relativizada assim qualquer invalidade daí decorrente -, mormente quando atente contra os princípios e valores imperantes no meio ambiente processual, a exemplo da efetividade, da segurança, da boa-fé e lealdade e do princípio do processo justo. O que importa, ao fim e ao cabo, é o formalismovalorativo."
} 
Nesse esteio, o Código de Processo Civil de 1973 já não se mostrava suficiente a amparar as relações jurídicas e sociais jungidas após a Constituição Federal de 1988, cujos preceitos são de observância obrigatória.

Conforme já enfatizado, zelou-se pela tutela constitucional do processo, mediante a inserção de princípios e regras destinadas a assegurar um processo justo e efetivo. Assim, os princípios do contraditório, devido processo legal e razoável duração do processo estabeleceram verdadeiras balizas de interpretação, criando um ambiente propício para as reformas infraconstitucionais.

Houve, de fato, significativas e variadas alterações no Código de Processo Civil de 1973, sintetizadas por Cândido Rangel Dinamarco (2001, p. 32) como "mini reformas". Dentre as mais relevantes, com o escopo de conferir maior efetividade e dinamismo ao processo civil, nos termos preconizados pela Constituição Federal, destacam-se os artigos 273, 461 e 461-A do $\mathrm{CPC}^{4}$, possibilitando antecipar, total ou parcial, os efeitos da tutela pretendida, assim como, a inserção da tutela específica nos casos de obrigação de fazer, não fazer e entregar.

Outras reformas disciplinaram diversos institutos processuais, como os recursos e reexame necessário ${ }^{5}$, contudo, talvez a modificação mais significativa tenha ocorrido em $2002,{ }^{6}$ por intermédio da alteração das regras dos processos de conhecimento e execução.

Evidentemente que se almejou, com as aludidas alterações dos institutos processuais, um processo que fosse mais alinhado aos ditames constitucionais, notadamente para ofertar um resultado processual justo, célere e efetivo.

Observa-se, todavia, que a modificação de diversos instrumentos processuais, repitase, de forma paulatina, muito embora representasse avanço às regras originais do Código de Processo Civil de 1973, ainda se revelava tímida frente aos bens jurídicos tutelados pela Constituição Federal, especificamente ao Estado Democrático de Direito (C.F, art. $1^{\circ}$ ).

Sendo assim, é fato induvidoso que a evolução das relações humanas, concretizada em decorrência de inúmeros fatores socioeconômicos, motivaram e até exigiram do Poder Legislativo a elaboração de um novo regramento que melhor se compatibilizasse com as novas ordens de valoração presentes na Constituição Federal.

4 Alterados por intermédio da Lei 8.952/94.

5 Leis 10.352, de 26 de dezembro de 2001 e Lei 10.358, de 27 de dezembro de 2001.

6 Lei 10.444/2002. 
O legislador, pressionado e sensível à necessidade de mudança, edita o Código de Processo Civil, com sanção em 16 de março de 2015 e vigência a partir de 18 de março de 2016. A rigor, pode-se afirmar que surgia primeiro Código de Processo Civil durante o regime democrático.

O sistema processual, portanto, almejava concretizar os princípios da magna carta, como verdadeiras balizas de interpretação, criando um regime processualista constitucional. Tanto que o artigo $1^{\circ}$ do Código de Processo Civil de 2015 refletiu tal mandamento, pois o processo civil será ordenado, disciplinado e interpretado conforme os valores e normas fundamentais estabelecidos na República Federativa do Brasil.

Em verdade, o CPC/2015 busca aplicar a tendência neoconstitucionalista, em que os textos constitucionais são, paulatinamente, dotados de concretização pelas orientações jurisprudenciais, conferindo-se ao poder judiciário importante papel no Estado de Direito Democrático, por intermédio da materialização dos bens jurídicos protegidos pela Constituição Federal.

Nessa medida, é desnecessário enfatizar à adequação e modernização de diversos institutos, correlacionados às garantias fundamentais do devido processo legal, como o princípio do contraditório. Às partes, que no diploma anterior tinham espaço de atuação limitada, detêm liberdade para, ao lado do magistrado, construírem solução voltada à pacificação do litígio. Nesse cenário, o CPC/2015 chega a ser intitulado por alguns como "o código das partes", tamanha a autonomia individual na busca por uma justiça célere, tempestiva e adequada.

Nas palavras de Humberto Theodoro Júnior (2015, p.80-81):

\footnotetext{
"Uma das bases da perspectiva democrática, trazida no Novo CPC, reside na manutenção da tensão entre perspectivas liberais e sociais, impondo que a comunidade de trabalho deva ser revista em perspectiva policêntrica e coparticipativa, afastando qualquer protagonismo e se estruturando a partir do modelo constitucional de processo, induzindo a convivência de poderes diretivos e gerenciais do juiz, com uma renovada autonomia privada das partes e dos advogados (como, v.g., na cláusula de negociação processual - art.190), mediante as balizas do contraditório como garantia de influência (art.10) e na fundamentação estruturada (art.489) que fomentarão o melhor debate de formação decisória e poderá permitir a diminuição das taxas de recursos, além de impor a diminuição do retrabalho processual na medida em que todos deverão exercer na primeira vez sua atividade com alta responsabilidade."
} 
Evidentemente que não se trata de conceber poderes ilimitados e incondicionais às partes, contudo, estar-se-á diante de interessante inovação na administração da justiça, em que o caráter liberal, de índole constitucional, representa a tônica processualista.

Em outra vertente, não menos importante, está a persecução pelo acesso à justiça no novo diploma, em que o cidadão tem o direito constitucional de levar a sua questão ao poder judiciário e obter uma resposta que seja, a um só tempo, efetiva e célere. É importante asseverar, nesse sentido, a proeminente necessidade do Estado prever meios para consagrar não só a entrada do cidadão ao Poder Judiciário, mas substancialmente, a sua saída, isto é, a forma com que deixa o litígio. De fato, a decisão judicial que concede o direito material da parte após longos anos de processo não se afigura justa, ainda que, de certo modo, seja efetiva (CPC, artigo $\left.4^{\circ}\right)$.

Relevante citar os doutrinadores Mauro Cappelletti e Bryant Garth (1991, p. 148), que dividem em três ondas os principais movimentos renovatórios do acesso à justiça. 1) A primeira onda refere-se à assistência judiciária aos necessitados para impedir a barreira financeira de ingressar em juízo; 2) A segunda onda, por sua vez, diz respeito a tutela dos interesses difusos, permitindo a judicialização dos conflitos de massa; 3) A terceira onda, por fim, remete a utilização de técnicas processuais adequadas para a solução do conflito, sendo que os operadores do direito devem adaptar-se a nova realidade.

Nessa toada, revela Kasuo Watanabe (1998, p. 67) que o direito de acesso à justiça deve compreender: o direito a informação; a formação organizada e operacional dos prestadores da justiça; a existência de instrumentos capazes de promover a tutela dos direitos, assim como, o afastamento dos eventuais empecilhos que possam dificultar a propagação do acesso à justiça.

De igual modo, um dos mais relevantes pilares que se sustenta o CPC/2015 é a busca pela pacificação social dos conflitos. É certo que a adoção de uma nova postura de enfrentamento ao dinamismo da relação conflituosa entre as partes tornou-se uma das metas da atualidade. Os meios colocados à disposição dos operadores do direito para a um só tempo, prestar a jurisdição e tutelar o direito material da parte ofendida, não se mostravam eficazes.

Nesse aspecto, o exponencial avanço das relações econômicas contribuiu para o surgimento dos conflitos de massa. Essa postura, enraizada nas premissas processuais do 
século passado, desencadeou a propositura exagerada de ações judiciais, assoberbando o trabalho dos juízes e serventias.

Assim é que, não por outra razão, prima-se pela autocomposição das partes, com base no autorregramento da vontade, como método extremamente eficiente para pacificar o litígio, ao invés da judicialização. Questão que merece destaque, aliás, é que esta forma amigável de composição não se restringe aos aspectos materiais objetos da disputa, mas se estende às regras processuais, por intermédio da correspondente regra de flexibilização prevista no artigo 190 do diploma, consagrando a previsão dos negócios jurídicos processuais atípicos.

Cabe asseverar que a solução negociada no processo civil encontra guarida no microssistema legal, por meio de inúmeros diplomas que incentivam a solução pacífica dos conflitos, como a mediação, conciliação, arbitragem (esfera privada); e transação penal, suspensão condicional do processo, leniência do cade, arbitragem na administração pública, acordo de colaboração premiada, acordo de não persecução penal e acordo de não persecução cível (esfera pública).

Claro que a recente alteração do ordenamento jurídico, com a promulgação de diversas Leis sobre o tema, encontra sustentáculo na Constituição Federal de 1988, cujo preâmbulo indica a opção da República Federativa do Brasil à solução pacífica da controvérsia. De igual sorte, até mesmo na esfera internacional há prevalência da tendência autocompositiva (CF, artigo $4^{\circ}$, VII).

Por essa razão, o Código de Processo Civil de 2015 tratou da questão logo em seu artigo $3^{\circ}, \S 2^{\circ}$ e $3^{\circ}$, ao disciplinar que o Estado promoverá, sempre que possível, a solução consensual do conflito. Esta regra, muito embora esteja no âmbito processual e, portanto, tem por finalidade estimular a composição a partir de um litígio, também se dirige ao gestor público, que deverá implementar políticas públicas que visem incentivar e estimular a realização da solução negocial.

João Pedroso (2002, p. 40), nesta perspectiva, defende que a judicialização deve ser reservada aos casos mais extremos e complexos, deixando que a sociedade resolva seus conflitos por meios alternativos extrajudiciais. Segundo o autor, a desjudicialização corresponde a quarta forma de resolução de conflitos, ao lado da conciliação, mediação e arbitragem. 
Não se pode olvidar que a propositura da demanda, em determinadas hipóteses, é necessária em face a pretensão resistida e impossibilidade de diálogo, assim deve ser preservada, o que não obsta, por óbvio, a busca por outras opções resolutivas menos traumáticas em que os envolvidos construam a solução de forma cooperada.

Nessa linha, os meios negociais consensuais objetivam estabelecer a pacificação social não apenas durante o processo mas, essencialmente, após o fim do litígio, com a intenção de estimular a continuidade da relação entre as partes.

Aliás, a busca pela consensualidade não é o único princípio norteador idealizado no Código de Processo Civil de 2015. Há, ainda, grande apelo pela boa-fé e cooperação entre as partes. O dever de cooperação exige que os sujeitos processuais estabeleçam um padrão comportamental lastreado na lealdade, colaborando entre si para a justa solução da demanda.

A solução dialogada surge como determinante para a resolução harmoniosa da lide, de modo que o magistrado, antes mero espectador, também converge e coopera com as partes.

Deve-se enfatizar que a construção do princípio cooperativo revela, sob o plano constitucional, a consagração do próprio Estado Democrático de Direito, cujo objetivo é propiciar a efetiva participação dos indivíduos na prestação jurisdicional, com a finalidade de construírem uma estrutura processual pautada no diálogo.

É bom esclarecer, por óbvio, que a divergência quanto ao objeto litigioso não impede às partes de colaborarem com a justiça, pautando-se com equidade e bom senso na busca pela resolução processual. É certo que a postura leal e recíproca reverte-se em favor das partes, seja ao sujeito que obteve a pretensão favorável em tempo célere e eficaz, seja àquele que não se sagrou vencedor, no entanto, teve os seus direitos absolutamente respeitados, sob a perspectiva constitucional do devido processo legal, seja ao Estado, porque os sujeitos processuais tendem a aceitar as decisões judiciais com mais naturalidade, sem a interposição de infindáveis recursos. Afinal, decisão justa é aquela que obedece aos preceitos constitucionais. ${ }^{7}$

7 Conforme Daniel Mitidiero, o processo justo se baseia em nove elementos necessariamente presentes, quais sejam: a) tutela adequada e efetiva, b) juiz natural, c) ampla defesa, d) paridade de armas, e) contraditório, f) direito à prova, g) processo em prazo razoável, h) publicidade, e i) dever de motivação; Mitidiero, Daniel. Elementos (...), cit. p.45 e ss. 
Nessa ordem, o artigo $6^{\circ}$ do Código de Processo Civil estabelece que todos os sujeitos do processo devem cooperar entre si para que se obtenha, em tempo razoável, decisão de mérito justa e efetiva. É de esclarecer, inclusive, que o princípio da cooperação processual espraia seus efeitos para outros dispositivos ao longo do texto processual, como se nota pela perfectibilização dos negócios jurídicos processuais (CPC, artigo 190).

É evidente que o dever de cooperação atinge não somente as partes, mas também o magistrado, que deve assumir uma postura pró-ativa em prol da lide. Exsurge para este o dever de consultar, esclarecer e auxiliar as partes, de modo que mesmo as questões de ordem pública não podem ser definidas sem que seja oportunizada a manifestação das partes.

Nesse sentido, tem-se a decisão judicial:

\footnotetext{
"O princípio da cooperação consiste no dever de cooperação entre as partes para o deslinde da demanda, de modo a se alcançar, de forma ágil e eficaz, a justiça no caso concreto. 3. $O$ indeferimento da petição inicial, sem a oportunidade de emenda, constitui cerceamento do direito da Autora, em verdadeiro descompasso com o princípio da cooperação." (TJ-DF AC 20150110703592, Data da publicação: 01/10/2015)
}

No mais, é preciso ter em mente que o CPC/2015 abandonou o apego ao formalismo exacerbado para consagrar o "formalismo valorativo", em que os ideais do processo são esteados por valores constitucionais e bases axiológicas, vale dizer, há uma releitura das regras processuais a partir dos princípios e preceitos da Constituição Federal, os quais servem de baliza aos intérpretes e aplicadores do direito ali transcrito.

Nas palavras de Carlos Alberto Álvaro de Oliveira (2006, p. 32), essa doutrina jurídica ultrapassa a visão do processo como técnica e diz "respeito à totalidade formal do processo, compreendendo não só a forma, ou as formalidades”, mas voltando a atenção também aos poderes e deveres dos sujeitos processuais, bem como à "ordenação do procedimento e organização do processo".

\section{O DISCURSO DE HABERMAS E O CÓDIGO DE PROCESSO CIVIL}

É induvidoso que o Código de Processo Civil de 2015 inaugurou uma nova era no sistema processualístico nacional. Ao tempo em que demonstrou desapego ao sentido literal existente na legislação, valorizou substancialmente a pacificação social calcada na solução 
dialogada das partes, seja por intermédio de técnicas resolutivas extrajudiciais ou mesmo pela propositura de ação judicial.

Neste vértice, a análise jurídica vinculada excessivamente à literalidade da Lei cede espaço com o novo diploma. Exsurge a interpretação teleológica, com o fim de permitir a inserção de elementos axiológicos para a subsunção do caso concreto às hipóteses legais. Assim, a mera adequação fática ao modelo geral e abstrato de conduta descrito pelo legislador não se coaduna com as diretrizes do Código de Processo Civil, exigindo que o intérprete empregue técnicas hermenêuticas fundadas na supremacia da Constituição, interpretação conforme a Constituição, consagração dos princípios da unidade, da razoabilidade e da efetividade das normas constitucionais.

Cabe ao julgador, por consequência, construir uma solução dialogada do fato posto em julgamento, de modo a possibilitar aos sujeitos processuais, ainda que tenham posições antagônicas entre si, a exteriorização de seus argumentos, exatamente como preceitua o princípio da dialeticidade.

É fato que a tônica evidenciada no Código de Processo Civil de 2015 remete à completa comunicação das partes e do magistrado, num ambiente igualitário e colaborativo do sistema processual, ainda que existe resistência quanto ao direito material. Não é crível que o juiz profira decisão sem que tenha oportunizado às partes o direito de influenciá-lo, consagrando os princípios do contraditório e igualdade. Este agir das partes, com base na comunicação, encontra correspondência nos ensinamentos de Jurgen Habermas, consoante se abordará.

Muito embora a teoria do agir comunicativo, idealizada por Habermas, tenha enfoque na esfera política, como contribuição extrema ao exercício da democracia, é certo que o seu ideal pode perfeitamente ser replicado na esfera jurídica, notadamente nos ideais materializados no Código de Processo Civil de 2015.

Evidentemente que o modelo constitucional adotado pela República Federativa do Brasil é o de Estado Democrático de Direito (C.F., artigo $1^{\circ}$ ), com ampla participação da comunicação para a concretização dos valores democráticos nele materializados.

Assim, para melhor compreender os preceitos gizados no Código de Processo Civil, especialmente a partir da perspectiva habermasiana, faz-se necessário analisar a teoria do 
agir comunicativo por ele desenvolvida entre os anos 70 e 80, com a finalidade de sedimentar, a um só tempo, o exercício da democracia e a propagação do conhecimento.

A teoria do agir comunicativo, segundo Habermas (1989, p. 166), seria:

\begin{abstract}
"processo circular no qual o ator é as duas coisas ao mesmo tempo: ele é o iniciador, que domina as situações por meio de ações imputáveis", bem como é o produto "das tradições nas quais se encontra, dos grupos solidários aos quais pertence e dos processos de socialização nos quais se cria"
\end{abstract}

Assim, a argumentação ganha especial relevo pois é a partir dela que as relações sociais são regidas, com preponderância de um discurso prático em detrimento da validade de uma norma incompreendida. E, por meio da comunicação consagra-se, em linhas gerais, o próprio exercício da democracia, desde que esta comunicação tenha contornos de validade.

Rogério Leal (2009, p. 406), por sua vez, acrescenta:

“(...) "todo o ato comunicativo carrega em si afirmações de validade (verdade, correção e sinceridade), em que a validade reivindicada é capaz de suportar críticas sob as condições de discurso, ou seja, um contexto de justificação argumentativa de suas pretensões que os participantes consideram irrepreensível.”

Nesse ambiente, a teoria do agir comunicativo pode ser difundida perante as obscuridades advindas do mundo da vida, em que a comunicação serviria de estímulo para o enfrentamento dos problemas vivenciados entre os indivíduos, que por sua vez, seriam causados justamente pela ausência de comunicação.

Assim é que, na visão de Luiz Cláudio Palermo (2013, p. 10):

[...] não obstante o fato de o mundo da vida estar inserido num plano maior dado pelo sistema, tal situação não elimina a possibilidade de acordos normativos realizados no mundo da vida influenciarem tanto a vida das pessoas e como mudanças em nível sistêmico. E esta é uma variável importante na construção oferecida Habermas, o que coloca em evidência a validade de sua teoria do agir comunicativo para o mundo moderno, em especial para a compreensão de sociedades complexas em termos políticos e econômicos, fato que favorece possibilidades que podem ser colocadas pelos agentes sociais, não sendo estes apenas produtos de regras ou classes que os envolvem e os dominam."

Por outro lado, percebe-se a facilidade de coexistir os ideais perfilhados por Habermas com os valores enraizados no Estado Democrático de Direito, cuja nota fundamental preceituada no artigo $1^{\circ}$, caput, da Constituição Federal, é o compromisso 
assumido com o cidadão de exercer a democracia de forma plena, com a participação de todos, em patamar de igualdade e com a plena possibilidade de influir na vida política e social. Há que se ressaltar, inclusive, a impossibilidade de conceder privilégios e favores para o exercício democrático, sendo inconcebível a atuação parcial dos envolvidos.

E, segundo Habermas (1997, p. 242):

"O princípio da democracia pressupõe preliminarmente a possibilidade da decisão racional de questões práticas, mais, precisamente, a possibilidade de todas as fundamentações, a serem realizadas em discursos (e negociações reguladas pelo procedimento), das quais depende a legitimidade das leis."

Logo, fácil perceber que a ideia de democracia colaborativa é o ponto comum entre o discurso habermasiano e o Código de Processo Civil. A esse respeito, o regime democrático representa, ainda que sob um enfoque extremamente simplista, a expressão da vontade do povo ${ }^{8}$.

Sob este viés democrático, o Código de Processo Civil de 2015 consagra a comunicação límpida e sincera entre as partes, regida pela lealdade, boa-fé e cooperação na busca de uma solução processual que atenda às diretrizes constitucionais. Este comportamento, esteado na constitucionalização do processo, almeja, a um só tempo, dirimir eventuais empecilhos processuais, com respeito ao devido processo legal e, ainda, a consensualidade quanto ao litígio material, que possibilite uma maior pacificação social.

Há no novo diploma processual, inegavelmente, opção pelo comportamento colaborativo e dialogado entre partes e magistrado, como se denota pelo dever de consulta do juiz, em referência ao princípio do contraditório, de acordo com o artigo $10^{\circ}$ : "O juiz não pode decidir, em grau algum de jurisdição, com base em fundamento a respeito do qual não se tenha dado às partes oportunidade de se manifestar, ainda que se trate de matéria sobre a qual deva decidir de ofício".

De igual sorte, quanto ao dever de esclarecimento constante no artigo 37, § $3^{\text {o: }}$ "Se a causa apresentar complexidade em matéria de fato ou de direito, deverá o juiz designar audiência para que o saneamento seja feito em cooperação com as partes, oportunidade em que o juiz, se for o caso, convidará as partes a integrar ou esclarecer suas alegações”.

8 Aprofundar a conceituação do instituto revela-se praticamente impossível, seja por ser tarefa extremamente complexa, seja por escapar dos objetivos visados no presente trabalho. 
Não se pode olvidar, inclusive, que o princípio da igualdade, outrossim, também assegura o ambiente democrático e comunicativo, com esteio no artigo $7^{\mathrm{a}}$ do CPC, ao disciplinar que "às partes paridade de tratamento em relação ao exercício de direitos e faculdades processuais, aos meios de defesa, aos ônus, aos deveres e à aplicação de sanções processuais, competindo ao juiz zelar pelo efetivo contraditório".

Também é o caso do artigo 190 do CPC, em que às partes, de maneira consensual e dialogada, podem flexibilizar o procedimento em benefício de ambos. Assim é que a comunicação encontra em Habermas e, em linhas gerais, no Código de Processo Civil, a solução para o convívio em sociedade. Este agir comunicativo afigura a principal maneira da pacificação social entre os sujeitos, como propagadores de consciência moral dirigida por princípios de justiça, com respeito a todo os integrantes e suas opiniões devidamente consideradas para, ao final, concretizar o consenso.

Para Habermas, a ação comunicativa reflete a interação entre as pessoas buscando a compreensão recíproca em prol de um ponto comum que satisfaça os interesses de todos.

Nesse sentido, Lilia Maia de Morais Salles (2004, p. 175) observa que a ação comunicativa modifica a relação entre os indivíduos, transformando o subjetivo em intersubjetivo, possibilitando maior compreensão do individual, e do coletivo e do bem estar social, permitindo a organização social, a elaboração e a validação de normas.

Exatamente nessa linha, o Código de Processo Civil incentiva, por intermédio do artigo $3^{\circ}$, parágrafos $2^{\circ}$ e $3^{\circ}$, a solução consensual dos conflitos, como a conciliação, mediação e arbitragem. Por esta ótica, a autocomposição consagra a liberdade individual do cidadão, pois cada indivíduo passa a ter o controle sobre os seus atos conflituosos e partir daí, parte para a construção da resolução pacífica da lide, essencialmente por considerar a argumentação, pretensão e anseio do oponente. Na realidade, o Código de Processo Civil de 2015 tornou obrigatória a realização de audiência de conciliação ou mediação antes da apresentação de contestação da parte ré.

Como preconiza Habermas, a atuação democrática e colaborativa permite que a decisão judicial traga um caráter pedagógico, com a missão de incutir na mente das pessoas e da sociedade, de maneira geral, que a lógica conflituosa não se idealiza com o próprio conceito de justiça.

Segundo ele, os atos de fala estão ligadas a três estruturas: a) cognitiva (natureza externa, mundo objetivo); b) normativa (natureza social, mundo social) e; c) expressiva 
(natureza interna, mundo subjetivo). Habermas acresce, inclusive, que existem condição transcendentais na linguagem.

Nesse prisma, a teoria da ética discursiva defendida por Habermas constitui instrumento voltado a aplicação das técnicas resolutivas extrajudiciais, como a conciliação e mediação, em que os pactuante, na condição de protagonistas e representantes do grupo social, por meio do diálogo cooperativo e instrutivo, buscam à pacificação, sem a imposição de qualquer meio coercitivo.

Desta forma, é de se concluir que a comunicação entre os envolvidos sentados à mesa conciliatória ocorre por meio da integração de fala e escuta, com plena ponderação de todos os argumentos e desenvolvimento de ideias, com respeito mútuo, destinados a possibilitar a exteriorização completa dos pensamentos individuais. Neste ponto, mais uma vez, assemelhase ao proposto por Habermas.

Assim, ao aderir à prática consensualista, a comunidade é tomada pela consciência de que conflitos podem ser prevenidos ou solucionados internamente, com o uso de técnicas de interação e promoção do diálogo que funcionarão junto com a comunicação e sua ação comunicativa, como instrumentos perfeitos para consolidação dos direitos fundamentais, da participação social e da democracia.

É bom ressaltar que ao prever e incentivar a utilização pelos métodos consensuais, o legislador possibilitou que as partes, mesmo após a propositura da ação judicial, cheguem ao consenso pelo uso da linguagem, o que também se coaduna com a teoria desenvolvida por Habermas.

\section{CONCLUSÃO}

Não pairam dúvidas que os instrumentos idealizados pelo Código de Processo Civil de 1973 e suas posteriores alterações não correspondiam integralmente às expectativas da sociedade. Suas regras, caracterizadas pelo formalismo extremo e inflexível, contribuíram para um sistema judicial moroso e inefetivo, causando descompasso do sistema processual e constitucional, especialmente quanto a violação ao princípio da razoável duração do processo. 
Edita-se o Código de Processo Civil de $2015^{9}$ com a missão de adaptar o processo civil aos anseios sociais e fortificar os valores materializados na Constituição Federal, mediante a preconização dos princípios e regras consagradas ao longo do texto. Essa nova era processual é denominada de constitucionalização do processo, consagrando-se o Estado Democrático de Direito.

Nesta perspectiva, o diploma processual traz ideais colaborativos entre as partes, com o fim de construírem uma estrutura processual pautada no diálogo e no ambiente democrático, conforme os seus interesses. Exatamente para cumprir tal mister, harmonizam-se os meios consensuais resolutivos com o sistema processual, com a finalidade de, a um só tempo, promover a pacificação social, desburocratizar o judiciário e diminuir o fluxo judicial.

Esta ideologia adotada pelo Código de Processo Civil de 2015, calcada na dialeticidade, democraticidade e ambiente colaborativo, foi influenciada pelo pensamento de Habermas, essencialmente a partir da teoria do agir comunicativo, em que os indivíduos tentam definir cooperativamente os seus planos de ação, levando em conta uns aos outros, no horizonte de um mundo da vida compartilhado. Além disso, estão dispostos a atingirem seus objetivos por meio do entendimento, que funciona com os participantes da interação.

Desse modo, observa-se que o ponto chave da ação comunicativa é o consenso, afinal, a comunicação linguística só tem sentido e razão de ser enquanto orientada no entendimento com o outro, o que faz com que aquele que se comunica fique atrelado às condições de racionalidade imanentes à ação comunicativa.

É possível identificar, portanto, o ponto comum entre o Código de Processo Civil de 2015 e o discurso de Habermas, qual seja, a construção da solução dialogada, democrática e pacífica das partes em prol da resolutividade, mediante o uso da linguagem hígida para atingir seus objetivos.

Não se olvida que outros institutos do sistema processual também preconizam a teoria habermasiana, os quais, são caracterizados pelo agir comunicativo entre os sujeitos do processo. Assim, a ideia de sabedoria do sujeito participante da relação processual vincula-se ao seu modo de agir e verbalizar.

Portanto, a racionalidade comunicativa, o agir comunicativo, a consciência moral e o conhecimento dialógico são pressupostos da Teoria da Ação Comunicativa apresentados como uma possibilidade de inter-relação com os institutos previstos no Código de Processo Civil de

9 A Lei 13.105 foi publicada em 16 de março de 2015, entrando em vigor 01 ano depois. 
2015, uma vez que a comunicação, a ação e a interação caminham para a promoção do desenvolvimento da solução pacífica dos conflitos, capaz de propiciar uma maior efetividade da justiça.

É fato que a comunicação mediada por um discurso coerente, receptivo e reflexivo contribui substancialmente para a resolução conflituosa, destinada a promover a idealização dos princípios constitucionais delineados no Estado Democrático de Direitos, quais sejam: a celeridade, efetividade e acesso à justiça.

\section{REFERÊNCIAS}

ALVARO DE OLIVEIRA, Carlos Alberto. O formalismo-valorativo no confronto com o formalismo excessivo. Revista de Processo, São Paulo, n. 137, 2006.

CAPPELLETTI, Mauro. O acesso à justiça e a função do jurista em nossa época. Revista de Processo. São Paulo: Editora Revista dos Tribunais, n. ${ }^{\circ}$ 61, p. 148-9. 1991.

Acesso à Justiça. Porto Alegre: Fabris, 2002.

CAPPELLETTI, Mauro; GARTH, Bryant. Acesso à justiça. Trad. Ellen Gracie Northfleet. Porto Alegre: Sérgio Antonio Fabris Editor, 1988, p. 31-73; e

CHIOVENDA, Guiseppe. Principios del derecho procesal. Madrid: Reus, s/d., p. 365.

DINAMARCO, Candido Rangel. A reforma do código de processo civil. 4. ed. São Paulo: Malheiros, 2001.

HABERMAS, J. Consciência moral e agir comunicativo. Rio de Janeiro: Tempo Brasileiro, 1989.

Direito e Democracia entre facticidade e validade. Vol II. Rio de Janeiro. Tempo Brasileiro. 1997.

JUSBRASIL. https://tj-df.jusbrasil.com.br/jurisprudencia/238432854/apelacao-civel-apc20150110703592. Acesso em 30 de jun. 2021.

JUSBRASIL. Previsões sombrias: 114 milhões de processos na justiça brasileira em 2020. https://espaco-vital.jusbrasil.com.br/noticias/150699708/previsoes-sombrias-114-milhoes-deprocessos-na-justica-brasileira-em-2020. Acesso em: 29 de jun. de 2021.

LEAL, R. G. Jurgen Habermas. In BARRETO, V. (Coord.). Dicionário de Filosofia do Direito. Rio de Janeiro, 2009, p. 403-408. 
MITIDIERO, Daniel Francisco. Elementos para uma teoria contemporânea do processo civil brasileiro. Porto Alegre: Livraria do Advogado, 2005.

PEDROSO, João. Percurso(s) da(s) reforma(s) da administração da justiça - Uma nova relação entre o judicial e o não judicial. Centro de Estudos Sociais, Observatório Permanente da Justiça Portuguesa. vol. 171. p. 1-43. Coimbra, abr. 2002. Disponível em: [www.ces.uc.pt/publicacoes/oficina/ficheiros/171.pdf]. Acesso em: 20.09.2015.

SALES, Lilia Maia de Morais, Justiça e mediação de conflitos. Belo Horizonte: Editora. Del Rey, 2004.

THEODORO JUNIOR, Humberto; NUNES, Dierle; BAHIA, Alexandre Melo Franco; PEDRON, Flávio Quinaud. Novo CPC - Fundamentos e Sistematização: Lei 13.105, de 16.03.2015. 2.ed.rev.atual.e ampl. Rio de Janeiro: Forense, 2015.

WATANABE, Kazuo. Acesso à Justiça e sociedade moderna. In: ; GRINOVER, Ada Pellegrini; DINAMARCO, Cândido Rangel (coord.). Participação e Processo. São Paulo: Ed. RT, 1988. 